\title{
"Haven't I Told You Not to Take Yourself OUTSIDE OF THE LAW?": RABBI YIRMIYAH AND THE Characterization of a Scholastic Sarah Wolf
}

\begin{abstract}
The paper looks at several episodes in which R. Yirmiyah is rebuked for questions that are portrayed as epistemologically destabilizing to the rabbinic legal project. I argue that R. Yirmiyah is portrayed as a caricature of late rabbinic scholastic thought, and that his characterization enables the writers of the Bavli to hold their own scholastic tendencies up to critique while also drawing protective boundaries around the analytical direction their legal culture has taken. I also read the passages together to demonstrate that the Bavli functions as a unified literary work in previously unacknowledged ways. These episodes form a sort of nonlinear plot, a web of stories that produce a character with his own "history." There may be no historical rabbinic nuisance named $R$. Yirmiyah, but there is certainly a constructed literary one, whose reappearance throughout the Talmud plays an important role in working out tensions within the rabbinic legal project.
\end{abstract}

Recent scholarship on rabbinic literature has debated the extent to which reflexivity and self-critique are present and salient in rabbinic literature; ${ }^{1}$ the extent to which scholasticism in Sassanian Persia impacted the formation of the Babylonian Talmud, also known as the Bavli; ${ }^{2}$ and how to understand the

1. See, for example, Ishay Rosen-Zvi, "Midrash and Hermeneutic Reflexivity: Kishmu'o as a Test Case," in Homer and the Bible in the Eyes of Ancient Interpreters, ed. Maren Niehoff (Leiden: Brill, 2012), 329-44; Christine Hayes, “'In the West, They Laughed at Him': The Mocking Realists of the Babylonian Talmud," Journal of Law, Religion \& State 2 (2013): 137-67; Hayes, What's Divine about Divine Law: Early Perspectives (Princeton, NJ: Princeton University Press, 2015); Ayelet Libson, Law and Self-Knowledge in the Talmud (Cambridge: Cambridge University Press, 2018).

2. Michael D. Swartz, "Scholasticism as a Comparative Category and the Study of Judaism," in Scholasticism: Cross-Cultural and Comparative Perspectives, ed. José Ignacio Cabezón (Albany: State University of New York Press, 1998), 91-114; Jeffrey L. Rubenstein, "The Rise of the Babylonian Rabbinic Academy: A Reexamination of the Talmudic Evidence," Jewish Studies: An Internet Journal 1 (2002): 55-68; Rubenstein, Talmudic Stories: Narrative, Art, Composition and Culture (Baltimore, MD: The Johns Hopkins University Press, 1999); Rubenstein, The Culture of the Babylonian Talmud (Baltimore, MD: The Johns Hopkins University Press, 2003); Mira Balberg and Moulie Vidas, "Impure Scholasticism: The Study of Purity Laws and Rabbinic Self-Criticism in the Babylonian Talmud," Prooftexts 32, no. 3 (Fall 2012): 312-56; Noah Bickart, "Tistayem: An Investigation into the Scholastic Culture of the Bavli" (PhD diss., The Jewish Theological Seminary of America, 2015). 


\section{"Haven't I Told You Not to Take Yourself outside of the Law?"}

nature of the Bavli as a literary text. ${ }^{3}$ This article contributes to each of these ongoing conversations by showing that the Bavli expresses self-critique about its own scholastic tendencies through the consistent characterization across multiple tractates of a particular rabbinic figure. I argue that through the Bavli's depiction of R. Yirmiyah as a problematically scholastic and somewhat liminal rabbinic figure, the Bavli expresses its own ambivalence about its increasingly metaanalytical approach towards law, while also reifying that tendency.

In four different passages in the Bavli, R. Yirmiyah is portrayed as asking a question that is quite similar to questions asked by other rabbis in other contexts, and in response he is harshly rebuked. R. Yirmiyah-who, it should be noted, is treated just like any other rabbi in hundreds of appearances throughout the rest of the Bavli-is told that by asking his question he is either removing himself from or must be removed from the bounds of scholarly discourse. R. Yirmiyah's questions take different forms and seem to address different concerns. A question at B. Rosh Ha-shanah 13a and its parallel at B. Sotah 16b address the ability of standardized rabbinic measurements to either account for anomalies or accurately assess a particular situation at all, while another pair of questions, at B. Bava Batra 23b and B. Niddah 23a, ask about the proper legal rulings for some unlikely liminal (in one case literally so) situations. The responses to the questions also differ: in the Rosh Ha-shanah and Sotah passages he receives a specially formulated rebuke; in the Niddah passage his question is met with a typical counterquestion about its legal significance, followed by $\mathrm{R}$. Aha b. Yaakov's statement that R. Yirmiyah had been attempting to make a joke; and in the Bava Batra passage he is thrown out of the house of study.

The appearance of these stories - and in particular the one in which he is actually thrown out of the rabbinic academy-has prompted both medieval ${ }^{4}$ and

3. Daniel Boyarin, Socrates and the Fat Rabbis (Chicago: University of Chicago Press, 2009); Barry Wimpfheimer, Narrating the Law (Philadelphia: University of Pennsylvania Press, 2011); Zvi Septimus, "The Poetic Superstructure of the Babylonian Talmud and the Reader It Fashions" (PhD diss., University of California, Berkeley, 2011); Itay Marienberg-Milikowsky, "Beyond the Matter: Stories and Their Contexts in the Babylonian Talmud-Repeated Stories as a Test Case" (PhD diss., Ben-Gurion University of the Negev, 2015).

4. Rashi, who suggests that R. Yirmiyah was thrown out for being annoying, seems to read the accusation that R. Yirmiyah is joking as a description of his behavior all along; the commentary attributed to Rabbenu Gershom (Gershom b. Judah, c. 960-1040) comments that R. Yirmiyah was annoying them specifically by asking them questions with no substance. Tosafot at B. Bava Batra $23 \mathrm{~b}$ reject the idea that R. Yirmiyah was thrown out for asking about an impossible scenario, which is apparently how the Tosafists understand Rabbenu Gershom's "questions with no substance," and explain that he was actually punished for the same offense as in B. Rosh Ha-shanah and B. Sotah: questioning the arbitrariness of rabbinic measurements. Rashba's (Shlomo b. Avraham ibn Aderet, 1235-1310), the Ran's (Nissim b. Reuven of Gerona, 1320-1376), and the Ritva's (Yom Tov b. Avraham Asevilli, c. 1260-1320) paraphrases of Tosafot ad loc. conflate the problem of asking an impossible question with the problem of doubting rabbinic measurements by taking a strongly nominalist position regarding the measurement given in the passage. R. Yirmiyah asks about the legal ruling for a baby bird that has hopped fifty 'amot and one half-step, but an anonymous voice states earlier in the passage that baby birds cannot hop more than fifty 'amot. Therefore, according to these medieval commentators, R. Yirmiyah is asking about a legally impossible situation because, as the Ritva puts it, by traveling 


\section{Sarah Wolf}

modern ${ }^{5}$ readers to wonder what was so problematic about R. Yirmiyah's questions, and to read the R. Yirmiyah stories in conjunction with each other in an attempt to discern an overarching theme that links them. It may not be fruitful, however, to look for a feature that makes R. Yirmiyah's questions inherently more problematic than any other question asked in the Babylonian Talmud. After all, readers of the Bavli do not have access to a question that exists independent of its framing in the sugya that can be analyzed to determine whether it was asked either derogatorily or in earnest. As James Frow has pointed out, the "equation of "character' with "person" - that is, the "humanist understanding of literary

more than fifty 'amot - even though the bird is hopping — "it has left the legal category of 'hopping' and is established in the legal realm of 'flying." See Novellae of Yom Tov b. Avraham Asevilli (Jerusalem: Mosad HaRav Kook, 2005), 196-97; see also Novellae of Shlomo b. Avraham ibn Aderet (Jerusalem: Mosad HaRav Kook, 1997), 411, and Novellae of Nissim b. Reuven (Jerusalem: Mosad HaRav Kook, 1996), 169-70.

5. Moshe Silberg reads R. Yirmiyah as expressing criticism of the rabbinic legal project, asking questions that are designed to point out the limits of halakhic formalism. "R. Yirmiyah's Questions: Methodology or Personality?," in Kitve Moshe Silberg (Jerusalem: Magnes, 1998), 151-59. See also Silberg, Kakh darko shel Talmud (Jerusalem: Mif'al Ha-shikhpul, 1961), 46-47. On the basis of a fifth story, in which R. Yirmiyah is reinstated to the house of study after submitting very humbly worded responses to rabbinic queries, Adin Steinsaltz argues that the problem with the Amora's questions to begin with was a lack of humility towards his fellows. "Why Was Rabbi Yirmiyah Removed from the Beit Midrash?," Sinai 54 (1963-1964). More recently, Eliezer Diamond has argued that R. Yirmiyah's questions are deemed unacceptable because they are either parodic or satirical forms of mockery. "But Is It Funny? Identifying Humor, Satire, and Parody in Rabbinic Literature," in Jews and Humor, ed. Leonard J. Greenspoon (West Lafayette, IN: Purdue University Press, 2007), 33-50. Diamond's arguments hinge on somewhat subjective judgments of parody. Diamond astutely points out that R. Yirmiyah's question about a bird with one foot in and one foot out of a boundary closely resembles a question elsewhere by R. Hanina about a man with one foot in and one foot out of the Shabbat boundary. He argues that R. Yirmiyah's question should be considered a parody of R. Hanina's because R. Hanina also appears earlier in the R. Yirmiyah sugya, and because Diamond considers the bird case to be much more absurd than the human case. He also judges R. Yirmiyah's question about R. Meir's position to be an "unacceptable" (to the rabbis) form of parody because it is disguised as a real question, which would not allow the recipient of the mockery to respond properly. Finally, Richard Hidary, in Rabbis and Classical Rhetoric: Sophistic Education and Oratory in the Talmud and Midrash (Cambridge: Cambridge University Press, 2018), discusses R. Yirmiyah's expulsion from the house of study in the context of rabbinic hypotheticals more generally. Hidary compares the Talmud's hypotheticals to Greek rhetorical exercises called controversiae, and concludes that "the Talmudic examples are somewhat more straightforward than their Greek parallels" (157), and that they are more likely meant to illuminate a legal principle than to generate an entertaining oration. Hidary acknowledges that, nonetheless, "the Mishnah and both Talmuds include very outlandish cases" (158), and provides a fairly traditional explanation for stories in which such hypotheticals are met with indignation: "The Bavli ... displays intolerance for absurd theoretical cases in many other instances where the context reveals that the question is meant as a challenge or personal insult rather than the test of a legal principle.... These examples suggest that the rabbis show intolerance to hypothetical questions specifically when they sense that the questioner seeks to undermine the authority of Jewish law by mocking its method of reasoning and attention to detail" (160). However, Hidary later suggests that the rabbis invented debates with Sadducees "to express their anxieties about their own legal derivations" (202), which more closely aligns with this article's interpretation of the R. Yirmiyah anecdotes. 


\section{"Haven't I Told You Not to Take Yourself outside of the Law?"}

character as the representation of autonomous, unified and self-identical subjects"-is an assumption that is specific to historical moments in readership, but is not always the best or most faithful understanding of a text. ${ }^{6}$ Instead of attempting to understand R. Yirmiyah as an autonomous being, then, we can acknowledge that we have only the problematic R. Yirmiyah character as presented to us by the Bavli's redactors. ${ }^{7}$ It is the literary features of the R. Yirmiyah stories - both the minimal "plot" of each story ending in his rebuke, as well as the development of $\mathrm{R}$. Yirmiyah as a character through a series of related anecdotes - that turn his questions into something more troubling and make it virtually impossible for the reader (or at least the reader who is committed to seeing the response to his questions as valid) to read them as questions asked in earnest. Thus, we may be better off asking: What do the producers of the Bavli convey by constructing a censure-worthy rabbi whose censurable deeds consist of asking fairly standard (at least for the rabbis) legal questions?

Daniel Boyarin argues in Socrates and the Fat Rabbis that the Bavli should be compared to Menippean satire in that it simultaneously performs and mocks an intellectual enterprise. For Boyarin, the apparent seriousness of the Talmud's legal enterprise is confounded by the Talmud's inclusion of grotesque narratives about the sages. He sees this as a form of self-critique: "It is as if the militant (philosopher, halakhist) says to herself one morning (or constantly): 'But what if I'm wrong.' This incessant self-critical voice, a voice of dialogue, contests with the voice of militant commitment that is the dominant 'accent' of the text, enabling a look into the abyss at the same time as the practices that prevent falling into the abyss (philosophy/Torah) are being avowed so passionately." ${ }^{8}$ According to Boyarin, the Bavli's voice of repression is the voice of law, whereas its voice of dissent is that of antilaw. Likewise drawing on Mikhail Bakhtin's theory of dialogism, Barry Wimpfheimer's Narrating the Law, despite arguing against the traditional Aggadah (narrative) versus Halakhah (law) dichotomy, similarly portrays the Bavli as containing two competing voices or drives. ${ }^{9}$ Wimpfheimer's and Boyarin's distinctions between the Talmud's competing energies, while not entirely identical, can be more or less encapsulated as follows: one drive represents systemic "statutes" (Wimpfheimer's "drive towards codification"; Boyarin’s

6. James Frow, "Spectacle Binding: On Character," Poetics Today 7, no. 2 (1986): 228. On the historical contingency inherent in the production, use, and meaning of characters, see also Deidre Lynch, The Economy of Character: Novels, Market Culture, and the Business of Inner Meaning (London: The University of Chicago Press, 1998). On character in rabbinic literature, see Ofra Meir, "Ha-demut ha-mishtanah ve-ha-demut ha-mitgalah be-sifrut hazal," Jerusalem Studies in Hebrew Literature 6 (1984): 61-77.

7. This is not to say that all of R. Yirmiyah's statements are redactorial inventions. It is entirely possible that before they entered the Bavli, these statements were part of an independently circulating collection of stories about the Amora. Nonetheless, by preserving them, highlighting their selfreferentiality, and presenting them in the context of passages involving legal fictions and strained argumentation, the redactors ultimately determine how the R. Yirmiyah anecdotes are received by the reader.

8. Boyarin, Socrates and the Fat Rabbis, 32.

9. Wimpfheimer, Narrating the Law. 


\section{Sarah Wolf}

monological stam) and the other drive represents antisystemic "stories" (Wimpfheimer's legal narratives; Boyarin's stam of the grotesque and carnivalesque).

The following analyses of the Rabbi Yirmiyah passages emphasize the imprecision of dividing the Bavli into these competing voices. ${ }^{10}$ While selfcritique and the grotesque may well be connected in the Bavli, both of those features are expressed through legal language as well as through narrativity. The questions in these passages are simultaneously absurd and law oriented, they serve the purpose of furthering a legal discussion while both adding to and drawing from the characterization of their asker, and they resemble the Bavli's typical legal discourse while also containing self-referential literary elements that unite them into a literary whole. Zvi Septimus has argued that the Bavli is meant to be read as a self-referential whole, and that the existence of certain "trigger words" that link stories across tractates shows that the intended reader of any one section of the Bavli is someone who already knows the entire text. ${ }^{11}$ The consistency of certain rabbi-characters across the Bavli, of which R. Yirmiyah is an important example, shows that the Bavli itself operates in some ways as a unified literary work beyond the level of Septimus's "trigger words." 12

The R. Yirmiyah anecdotes also demonstrate the Bavli's literary interconnectedness and use of characterization beyond what are typically considered to be aggadic, or more traditionally narrativized, texts. Devora Steinmetz has also argued that "the Bavli assigns to certain sages specific tendencies which are constructed and conveyed through the interrelationship of a range of passages,"13 which she describes as "a network, or web, of texts." 14 My reading of the repeated

10. See also Mira Wasserman, who notes in Jews, Gentiles, and Other Animals: The Talmud after the Humanities (Philadelphia: University of Pennsylvania Press, 2017), "I would argue that the Bavli's provocations are in no way limited to narrative, but pervade passages that are structured as legal dialectic as well" (30). For a slightly different analysis and critique of Boyarin's and Wimpfheimer's reads of the Talmud's dialogism or lack thereof, see Moshe Simon-Shoshan, "Talmud as Novel: Dialogic Discourse and the Feminine Voice in the Babylonian Talmud," Poetics Today 40, no. 1 (March 2019): 105-34. Simon-Shoshan questions Boyarin's and Wimpfheimer's engagement with Bakhtin, arguing that the Talmud is - according to Bakhtin's analytical framework-more novelistic in its dialogism and heteroglossia than Simon-Shoshan's two talmudist interlocutors allow. While the Talmud indeed self-subverts in more complex ways than have been acknowledged, Simon-Shoshan, too, divides the Talmud into two in his discussion of a group of "alternative voices" (also implicitly narrativized) that stand in opposition to the authoritative stam.

11. Zvi Septimus, "Trigger Words and Simultexts: The Experience of Reading the Bavli," in Wisdom of Batsheva: The Dr. Beth Samuels Memorial Volume, ed. Barry Wimpfheimer (Jersey City, NJ: Ktav, 2009); see also Septimus, "Poetic Superstructure."

12. The characterological consistency of R. Yirmiyah across these passages also offers a definitive rebuke to Yonah Fraenkel's theory of "external closure" in rabbinic stories; see Fraenkel, "Hermeneutic Problems in the Study of the Aggadic Narrative,” Tarbiz 47 (1978): 139-72. See also Rubenstein, Talmudic Stories, 254-55.

13. Devora Steinmetz, "Agada Unbound: Inter-Agadic Characterization of Sages in the Bavli and Implications for Reading Agada," in Creation and Composition: The Contribution of the Bavli Redactors (Stammaim) to the Aggada, ed. Jeffrey L. Rubenstein (Tübingen: Mohr Siebeck, 2005), 295.

14. Ibid., 309. 


\section{"Haven't I Told You Not to Take Yourself outside of the Law?"}

themes in R. Yirmiyah's portrayal in legal passages expands on this argument by showing that the Bavli employs such characterization in less story-like, more primarily legal passages.

The presence of several interconnected R. Yirmiyah stories, many of which seem to assume a preexisting understanding of R. Yirmiyah's character and history, shows that the Bavli employs a literary unifier to create a sense of selfreferentiality within its legal discussions: that is, the use of characterization through repeated plot elements. In the case of R. Yirmiyah, such elements include the portrayal of R. Yirmiyah as a performer of legal meta-analysis, the persistence of R. Yirmiyah's questions and their seemingly inevitable rebuke, and the appearance of R. Zeira as R. Yirmiyah's foil. ${ }^{15}$ The R. Yirmiyah stories thus reveal a way in which the "halakhic" portions of the Bavli also function as narratives, creating a multipart dramatic story about a liminal character that runs throughout the entire text.

I argue that R. Yirmiyah is portrayed in these stories as the Ultimate Scholastic, and, therefore, as deserving of the most serious rebuke. Late rabbinic literature was composed within an increasingly scholastic context in Sassanian Persia, and it reflects this context in its depiction of the rabbinic academy, its treatment of scholastic cultural themes, and its depiction of its own legal processes. ${ }^{16}$ Two of the central features of scholasticism as a cross-cultural category, as defined by José Cabezón, are intellectual orientations towards "the epistemological accessibility of the world: the belief that the universe is basically intelligible" and "self-reflexivity: the tendency to objectify and to critically analyze first-order practice." ${ }^{\prime 17}$ Another key feature of scholastic culture, especially in oral cultures, is an emphasis on dialectics and debate, even to the point of verbal "violence." 18 As I will show, each of these elements is either integral to or imposed upon R. Yirmiyah's questions, and is additionally emphasized in the responses he receives. R. Yirmiyah's questions in this group of legal stories all treat the law as an object for hypothetical contemplation rather than real-life application. They also share an overarching concern: the ability of rabbinic law to describe the natural world, especially when it manifests in a messy or unusual way. Each of the questions pits legal presumptions or legal fictions-about determining

15. R. Yirmiyah and R. Zeira, who are portrayed as a teacher/student pair, also appear in the context of other sorts of interactions throughout the Bavli, most of which do not fit the paradigm of the examples presented here. However, it is worth noting their interaction at Shabbat 10a, in which the tables are turned and R. Yirmiyah sharply rebukes R. Zeira for cutting short their analysis of rabbinic sayings in order to pray. This episode, in which R. Yirmiyah demonstrates his preference for study over other expressions of religious life, further supports my argument here that R. Yirmiyah is characterized in the Bavli as scholastic to an extreme.

16. In addition to the sources cited above, see Adam H. Becker, "The Comparative Study of 'Scholasticism' in Late Antique Mesopotamia: Rabbis and East Syrians," AJS Review 34 (2010): 91-113. For more on the Syriac Christian schools in particular, see also Becker, Fear of God and the Beginning of Wisdom: The School of Nisibis and the Development of Scholastic Culture in Late Antique Mesopotamia (Philadelphia: University of Pennsylvania Press, 2006).

17. Cabezón, Scholasticism, 5-6.

18. Rubenstein, Culture of the Babylonian Talmud. 
ownership, quantifying grain growth, or determining the status of an anomalous birth-against the possibility that reality may be either too complex or too unknowable for those legal presumptions to accurately judge. ${ }^{19}$ Additionally, the story of R. Yirmiyah's return to rabbinic favor seems to imply that one of his "crimes" was insufficient deference in his exchanges with colleagues, perhaps thus expressing a critique of scholastic verbal sparring.

These features of scholasticism are expressed in different ways throughout the Bavli, and are in no way unique to R. Yirmiyah or the set of legal narratives presented here. Rather, the Talmud's redactors produce the character of R. Yirmiyah as the Problematic Scholastic precisely in order to voice doubt about the Talmud's own increasingly abstract and scholastic approach towards law, while simultaneously repressing that doubt within the structure and rhetoric of the passages in which these moments occur. Even if R. Yirmiyah's questions could be read as "straight"- that is, earnest attempts to apply rabbinic law to unusual cases or to question the utility of the law-the fact that their literary framing all but forces the reader to interpret them as subversive betrays selfconsciousness and discomfort about this aspect of rabbinic legal activity. The creation of a character who is rebuked for asking questions that push at the limits of rabbinic legal fictions - whether earnestly or not-shows that such activity was a source of tension for the character's creator(s). ${ }^{20}$

The R. Yirmiyah anecdotes also tend to appear within passages whose logic is somewhat difficult to accept, whether it is the establishment of a rabbinic legal presumption on the basis of shaky interpretive grounds, or the reinterpretation of a mishnaic metaphor as a statement of ontological fact, or the attempt to establish a

19. On legal fictions in general, see Lon Fuller, Legal Fictions (Stanford, CA: Stanford University Press, 1967); Avram Soifer, "Reviewing Legal Fictions," Georgia Law Review 20, no. 871 (1986): 871-915; Frederick Schauer, "Legal Fictions Revisited," Virginia Public Law and Legal Theory Research Paper Series, no. 2011-29 (2011). On legal fictions in rabbinic literature, see Leib Moscovitz, "Rabbinic Legal Fictions," in Legal Fictions in Theory and Practice, ed. Maksymilian Del Mar and William Twining (Switzerland: Springer, 2015), 325; Christine Hayes, "Authority and Anxiety in the Talmuds: From Legal Fiction to Fact," in Jewish Religious Leadership: Image and Reality, ed. Jack Wertheimer (New York: The Jewish Theological Seminary, 2004), 127-54; Tzvi Novick, "They Come against Them with the Power of the Torah: Rabbinic Reflections on Legal Fiction and Legal Agency," in Studies in Law, Politics and Society, ed. Austin Sarat (Bingley, UK: Emerald Group, 2009), 1-17; Elana Stein, "Rabbinic Legal Loopholes: Formalism, Equity and Subjectivity" (PhD diss., Columbia University, 2014). On legal fictions in late antiquity, see Clifford Ando, Roman Social Imaginaries: Language and Thought in the Contexts of Empire (Toronto: University of Toronto Press, 2015).

20. R. Yirmiyah is not the only character through which the rabbis play out ambivalence around their own cultural norms. Daniel Boyarin points out another example in his analysis of the series of sugyot in B. Ketubot about scholars who leave their wives for extended periods of time to study, culminating in one version of the story of R. Akiva and his wife: "The absolute and contradictory demands of marriage and commitment to study of Torah remained one of the great unresolved tensions of rabbinic culture. The text thematizes that tension by 'personifying' its poles. This is to be taken as neither an assertion nor a denial of the biographical, historical 'reality' of these Rabbis and their discourse, but only as an interpretation of the function that the text plays, in my reading, in rabbinic culture." Carnal Israel: Reading Sex in Talmudic Culture (Berkeley: University of California Press, 1993), 134. 
blanket conceptual rule about competing legal principles that clearly contradicts the established approaches to certain legal questions. I argue that the rebuke of $\mathrm{R}$. Yirmiyah in the context of these passages is not a coincidence, but rather an outlet for release for the tension built up by strained argumentation.

Just as R. Yirmiyah's questions are not in and of themselves unique, such moments of strained logic are also not out of the ordinary for the Bavli. Rather, the appearance and rebuke of R. Yirmiyah the Ultimate Scholastic in these passages represents a moment of rabbinic self-criticism interrupting the flow of rabbinic legal work, in which occasional logical difficulties are mostly taken in stride. In these moments, R. Yirmiyah is treated as though he has embarrassingly revealed the scholasticism at the heart of all rabbinic work - that is to say, its ultimate orientation towards the performance of intellectual group identity as instantiated through attitudes towards both texts and other interpreters.

The R. Yirmiyah anecdotes thus reveal two significant and somewhat related features of the Bavli's legal discourse. First, the Bavli's creators seem to be conflicted about the scholastic nature of their legal discussions, and particularly the relationship between their legal presumptions and the natural world. And second, the legal discourse of the Bavli also functions as a vehicle for storytelling, a forum for working out cultural concerns not just through legislation but through more typically literary tools such as characterization. Examining these stories can thus help us to understand how the rabbis of the Talmud understood their intellectual project - a legal discourse that is far more than a guide to practical law, but one that betrays competing tendencies towards manifestation in reality and manifestation in the minds of its interpreters.

In a passage beginning at B. Rosh Ha-shanah 13a, R. Yirmiyah is rebuked by his teacher and colleague R. Zeira for asking a question that casts doubt on the correspondence between formalized rabbinic measurements and reality. R. Yirmiyah's question expresses a typically scholastic concern for epistemological certitude, which R. Zeira seems to view as antithetical to the goal of producing practical legal opinions.

The passage begins with a discussion of the mechanism for determining whether produce is legally considered to have grown during a Sabbatical Year. Since everything that is grown in the Sabbatical Year (every seven years) is forbidden for use, the rabbis must develop a standard for determining which grain should be categorized as forbidden sabbatical produce. Is such categorization based on the year the grain was harvested or on the year it was planted? In order to answer this question, the rabbis turned to an analogous legal domain. The standard for making such determinations regarding tithing, according to a mishnaic statement quoted in this passage, is based on a cutoff somewhere in between. If the grain grew one-third of its total growth during the final year of counting, then no matter when it was harvested, it is considered titheable - and presumably, by analogy, sabbatical-produce. ${ }^{21}$

21. M. Ma aserot 1:3, on the threshold for plants' legal significance with regard to tithing. See also M. Hallah 1:3. 


\section{Sarah Wolf}

The passage at hand, which leads into R. Yirmiyah's question, begins as though it is going to provide a biblical justification for this standard, asking, "From where are these words?" Yet neither the legal midrash that follows nor its subsequent discussion provide biblical proof for the one-third standard, though the passage reads as though it has. ${ }^{22}$ This hermeneutic tension is an important backdrop for the exchange between R. Yirmiyah and R. Zeira that follows, which serves as an outlet for the passage's unacknowledged textual difficulties.

The initial legal midrash does not provide an explanation for the one-third growth standard, either for tithing or for sabbatical produce, but instead brings in a new factor not mentioned in the Mishnah: the Feast of Booths, which is a harvest festival that occurs two weeks into the beginning of the year.

We taught elsewhere: "Grain and olives [are tithable] from when they grow one-third."

From where are these words? R. Asi said in the name of R. Yohanan, and they brought it in the name of R. Yose the Galilean: Scripture says "At the end of every seven years, at the time of the year of release, on the Feast of Booths" [Deut 31:10].

What does the year of release have to do [with the Feast of Booths]? ${ }^{23}$ [The Feast of Booths falls in] the eighth year!

Rather, it teaches you that for all grain that grew one-third in the seventh year before the New Year, you must behave towards it with the customs of the seventh year in the eighth year. (B. Rosh Ha-shanah $12 b)^{24}$

According to this midrash, Deuteronomy mentions the Feast of Booths in the same verse as the Sabbatical Year in order to teach the standard about one-third growth. The logic seems to be as follows: because the Feast of Booths occurs two weeks into the beginning of the eighth year, the holiday's appearance in the verse about the Sabbatical Year is meant to convey the notion that some plants that seem to be eighth-year plants, because they are harvested in year eight, are really seventh-year plants (thus clarifying that the year in which the grain is harvested is not the deciding factor). ${ }^{25}$

Yet, although the midrash purports to explain why the standard for grain is one-third of its growth, it never makes any explicit connection between that

22. A midrashic justification is eventually brought later in the text: "R. Yonatan b. Yosef says, 'And it shall bring forth produce for those three years' [Lev 25:21]: Do not read 'three' [שלש] but rather 'one-third' [שליש].” B. Rosh Ha-shanah 13a-b.

23. Bracketed phrase attested in JTS Rab. 1608 (EMC 850) and London manuscripts, as well as Pesaro, Venice, and Vilna prints.

24. All translations are mine. All texts of the Talmud in this article are based on the Vilna print edition due to minimal variations between manuscripts, but variants are noted in footnotes where appropriate.

25. A similar midrash, upon which this passage is likely based, appears in Sifra, Be-har, section 1: "R. Yonatan b. Yosef says: From where do we know that if grain grew a third before the New Year [of the eighth year], you gather it in [i.e., it is legally part of] the Sabbatical Year? Scripture says, 'and you harvest your grain'- even from when it has grown one-third” (JTS Rab. 2171 [MS 9026], 135b). 


\section{"Haven't I Told You Not to Take Yourself outside of the Law?"}

standard and either the Sabbatical Year or the eighth-year harvest festival. The understood link between the two might be motivated in part by the Tosefta at Shevi'it 2:7, which specifically mentions the idea of retroactive tithing of (at least some part of) plants that were harvested in the following year if they grew one-third before the New Year-but even there, the connection seems to be merely incidental and not causal. ${ }^{26}$

The connection between the Feast of Booths and the one-third of growth is at least partially explained in the subsequent discussion of the midrash:

\section{R. Zeira said to R. Asi: But perhaps it did not grow at all and Scripture says to let it lie fallow until the Feast of Booths? \\ Do not think that, for it is written: "The harvest festival at the end of the year" [Ex 23:16]. \\ What is "harvest"? If you will say it is the holiday that happens at the time of the harvest, it is already written "When you harvest"! \\ Rather, what is "harvest"? Cutting down. And the rabbis knew that for any grain that was [fit to be] harvested on that holiday, it was certain that it had grown a third before the New Year, and it was called last year's grain.}

R. Zeira, questioning the legal midrash, asks whether the Feast of Booths is really mentioned in the verse in order to convey the standard of one-third growth, or whether it simply means that the standard is based on the time of planting, and that as long as the grain was planted at any point during the seventh year it cannot be harvested in the eight year, whether it grew one-third or not. This indeed seems to be a much more straightforward interpretation of the verse. However, the Talmud's anonymous voice, seemingly taking the side of R. Asi, argues in response that the mention of the harvest festival (i.e., the Feast of Booths) in a different verse about the Sabbatical Year is not merely there to provide a date, since that would be redundant, but to signify actual harvesting. If the grain is fit for harvest at that date, according to this reading of the second verse, the rabbis could then know that it must have grown one third of its growth by the New Year two weeks earlier. The conclusion of the midrash's explanation ultimately fails to show any textual connection between the eighth-year harvest festival and the one-third standard, even though this is what it purports to do. Instead, it presents readiness for harvest on the Feast of Booths as a rabbinically established-but not biblically or even midrashically justified-legal presumption that allows the rabbis to determine whether grain had grown one-third in the previous year or not.

At this point in the discussion, R. Yirmiyah asks his question to R. Zeira: "And were the rabbis certain [about the distinction] between a third [growth]

26. "Dill and coriander that were planted for greens, even if they took root before the New Year and were harvested after the New Year, must be tithed, and at the time of their harvest they [become] forbidden [if not tithed]. One may tithe from its seeds in place of its greens or from its greens in place of its greens [MS Erfurt: its seeds], and if it grew one-third before Rosh Ha-shanah, its seeds are tithed retroactively, and its greens according to the time of its harvest" (MS Vienna). 


\section{Sarah Wolf}

and less than a third?" R. Yirmiyah's question seems not to follow logically from the anonymous statement immediately preceding it. The explanation of the midrash in no way assumes that the rabbis know how to distinguish between, say, less than a third of growth one day and a third of growth the next - which is more or less the way R. Zeira interprets R. Yirmiyah's question. In fact, this explanation quite nicely accounts for total rabbinic inability to do so by establishing the legal presumption that grain harvested on Sukkot must have already reached a third of growth on or before a date about two weeks earlier! R. Yirmiyah's question may thus be understood instead as casting doubt on the correspondence of this rabbinic legal presumption, whose midrashic basis is dubious at best, with reality. When it appears at this juncture in the passage, then, R. Yirmiyah seems to be saying: You may have a legal mechanism for determining one-third growth based on readiness for harvest on the Feast of Booths, but given the lack of either a real justification for this standard's biblical basis or the ability to verify its correspondence with natural reality, how can they know that this mechanism produces law that corresponds with truth? ${ }^{27}$

In response, R. Zeira rebukes R. Yirmiyah, saying, "Haven't I told you not to take yourself outside of hilkheta?" The term hilkheta in the Bavli designates not law as a form of discourse, such as the back-and-forth argumentation typical of the Bavli's "legal" sections, but specifically the formulation of an applicable legal ruling. ${ }^{28}$ The peculiar wording of R. Zeira's response thus portrays R. Yirmiyah's question as departing from the bounds of practical law. When he accuses R. Yirmiyah of "taking himself outside" of the production of hilkheta, that is, practical law, R. Zeira may be pointing out that R. Yirmiyah risks undermining the law's utility when he questions the accuracy of formalized legal measurements, since it would be impossible to generate usable rules if the law had to account for all individual circumstances. ${ }^{29}$ However, one can also read R. Zeira's warning not just as defense of formalistic legal presumptions in rabbinic law, but as an admonishment that such concern about the law's epistemological accuracy - a typically scholastic concern - is outside the realm of acceptable rabbinic discourse. ${ }^{30}$

R. Zeira continues his rebuke with the explanation that all rabbinic measurements are "like that," followed by a list of rabbinic legal standards whose precise

27. R. Yirmiyah's question may well not have originated in a context in which the midrashic explanation was also present. However, the Bavli's redactors contribute to R. Yirmiyah's ongoing characterization here by arranging the sugya in a way that portrays R. Yirmiyah as casting doubt not only on the ruling but on its midrashic justification as well.

28. Yaakov Spiegel, "Hosafot me'uharot (savora'iot) ba-Talmud ha-Bavli” (PhD diss., Tel Aviv University, 1976), 164.

29. Cf. Silberg, "R. Yirmiyah's Questions."

30. The idea that such a question is simply unacceptable seems also to be Rashi's understanding, based on the language he uses to explicate the line "Do not take yourself outside of hilkheta" at Sotah 16b: "All of the words of the sages that have been fixed, do not ponder them too much" (על תהרהר אחריהן). 


\section{"Haven't I Told You Not to Take Yourself outside of the Law?"}

measurements determine whether an object or a situation falls into one category or another.

He [R. Zeira] said to him [R. Yirmiyah]: All the measurements of the sages are like that. One immerses in [a ritual bath of] forty se'ot; in forty se'ot minus a kortov one cannot immerse. An egg-amount transmits food impurity; an egg-amount minus a sesame seed does not transmit food impurity. ${ }^{31}$ Three by three [tefahim] transmits impurity by treading; three by three minus one hair does not transmit impurity by treading. ${ }^{32}$

This response does not seem to fit well with R. Yirmiyah's question. R. Yirmiyah wanted to know whether the rabbis were truly able to distinguish one type of produce from another on the level of externally verifiable fact-had the produce actually grown one-third or not? This part of R. Zeira's response, on the other hand, deals with cases where the standard for distinguishing two legal categories is clear (forty se'ot are objectively measurable in a way that "one-third growth" is not), and there is no such thing as external verifiability - the truth about impurity or purity, or the validity of a ritual bath, are "facts" created by the rabbinic legal standard that do not exist outside of them. As Mira Balberg and Moulie Vidas

31. MS Munich 95: "Minus some amount [משהו]."

32. R. Zeira's particular rebuke to R. Yirmiyah also appears in this passage's parallel at B. Sotah 16b, which deals with the sacrifice of a swallow whose blood must be recognizable when mixed with water. An anonymous legal ruling states that the proper amount of water to achieve this effect is one-quarter $\log$ (about an eighth of a liter) of water. Following this ruling, R. Yirmiyah asks R. Zeira about the legal consequences of an abnormally sized bird. He responds "Haven't I told you not to take yourself outside of hilkheta? The rabbis measured based on a swallow. You do not have a large one that displaces the water or a small one that is displaced by the water." R. Yirmiyah's question in this parallel passage yet again expresses concern that one-size-fits-all legal rules will not correspond with the realities of the natural world. Whereas in the B. Rosh Ha-shanah passage, R. Yirmiyah expressed doubt about the ability of the rabbinic legal presumption to generate epistemologically valid knowledge, here R. Yirmiyah's question expresses concern about the way in which the formalized legal rule discounts the possibility of aberrations from the norm. This question thus seems more suitable to R. Zeira's response about "all the measurements of the sages": Just as a mikveh is only functional at forty se'ot because that is standardized as the right size to fit a human, even though one could theoretically have a small person who needed less than forty or a large person who needed more, the quarter $\log$ of water remains the same regardless of the size of the bird being slaughtered. R. Yirmiyah's question here is also quite similar to questions asked elsewhere in the Bavli by other Amoraim, who are also told that "all the measurements of the sages are like that." At B. Ketubot 104a, R. Yosef says "all the measurements are like that" in response to Abbaye, who had expressed astonishment that the moment it takes for the sun to set is considered significant enough for a woman to give up her right to her ketubah payment. And at B. Menahot 103b, R. Shimon says it to R. Yehudah b. Ilai, who had asked how it can be that sixty-tenths of a meal-offering can be combined in one vessel, but not sixty-one-tenths. Those rabbis, however, are not told that they are "taking themselves outside of hilkheta," and R. Yirmiyah in this passage does not receive an explanation about standardized rabbinic measurements. Instead, R. Zeira's response here repeats the warning about "taking yourself outside of hilkheta," and then states that the rabbis prevented possible variations on the size of bird by mandating a single species of bird of which there are no especially large or small specimens. 


\section{Sarah Wolf}

have pointed out, "the sage who studies purity and impurity ostensibly purports to make truth claims about the world itself. However, the rabbis were very much aware that they were not really revealing a 'truth': rather, they were engaged in a scholarly activity in which they certified things as pure or impure through processes of dialectical reasoning." ${ }^{33}$ Balberg and Vidas describe a rabbinic "tension between description and construction"; whereas purity laws fall closer to the side of construction, sabbatical produce-at least when it comes to the question of how much it grew and when - deals much more with description.

R. Yirmiyah also does not call the measurement arbitrary-an accusation to which R. Zeira seems to be responding - but rather expresses concern that it might not be possible to apply it in a way that corresponds with reality. His question, in other words, is not about the law's formalism but rather about epistemological validity. Perhaps in part because of this distinction and perhaps also because of his unique characterization, R. Yirmiyah therefore also receives the unique response accusing him of asking a question that is outside the realm of practical law. R. Zeira's response here is thus part of the literary construction of R. Yirmiyah as a scholastic who is concerned more with meta-analysis of the law than its practical implementation. This passage's contribution to an ongoing characterization of R. Yirmiyah is further emphasized by the phrase "Haven't I told you," which indicates that these exchanges between R. Zeira and R. Yirmiyah are not isolated incidents but part of an ongoing pattern. ${ }^{34}$

The characteristics emphasized by R. Yirmiyah's question and its rebuke in this passage include a tendency towards self-reflexivity, and-as one manifestation of that $-a$ concern about epistemological validity, and in particular whether or not rabbinic epistemology matches up with determinations of reality. For R. Zeira, this metalegal concern is "outside" the bounds of acceptable rabbinic thought, much as elsewhere in rabbinic literature excessive mystical contemplation is discouraged. (It is worth noting that one rabbi who is too engaged in such mystical thoughts is, just like R. Yirmiyah, portrayed by a colleague as - presumably ideologically_-"outside." $)^{35}$ According to R. Zeira, R. Yirmiyah should not be concerned with the pursuit of some kind of deeper truth, but rather with the pursuit of applicable rulings.

Following R. Zeira's rebuke, R. Yirmiyah recovers by taking back his question. However, in the process of claiming that his epistemological doubt

33. Balberg and Vidas, "Impure Scholasticism," 340.

34. A similar reference to R. Yirmiyah's pattern of behavior can be found in a passage in the Palestinian Talmud in which R. Yirmiyah is threatened with expulsion: "R. Yirmiyah still has not turned from his wickedness" (Y. Mo 'ed Katan 3:1 [81d]). Though none of the Bavli passages analyzed here has a direct parallel in the Yerushalmi as far as their portrayal of R. Yirmiyah, the Mo'ed Katan reference may indicate that the R. Yirmiyah anecdotes in the Bavli originated from a previously established trope, perhaps even an independently circulating collection of stories. Whatever the anecdotes' history may be, however, the literary effect of their dispersion throughout the Bavli is still one of ongoing and self-referential characterization.

35. B. Hagigah 15a: "R. Yehoshua said to his students: Ben Zoma is still outside." 


\section{"Haven't I Told You Not to Take Yourself outside of the Law?"}

was misguided, he also reestablishes the validity (if not relevance) of his question by pointing out that it has already been asked.

R. Yirmiyah responded: What I said was wrong, for the sages asked Rav Kahana: The 'omer that the Israelites brought when they entered the land, where did they bring it from? If you will say they brought it from non-Jews, the Torah says "your harvest" [Lev 23:10] —and not the harvest of a non-Jew.

How do we know they brought it? Maybe they didn't bring it!

Don't think that, for it is written, "And they ate from the produce of the land from the day after Passover" [Josh 5:11] — from the day after Passover it was eaten; [therefore] beforehand it was not eaten. Thus, they brought the 'omer and then they ate.

From where did they bring it?

He said to them: Anything that was not yet one-third ripe belonging to a non-Jew. ${ }^{36}$

And perhaps it grew and they didn't know?

But they did know. [And] here too, they did know.

In R. Yirmiyah's explanation of why his question was unnecessary, he points out that the same question had already been asked of R. Kahana in another context. Because R. Kahana had explained to the sages that their doubt was unfounded, R. Yirmiyah understands that his doubt is unfounded as well. Yet the fact that an anonymous group of sages had asked the exact same question without being rebuked is yet another indication of the fact that R. Yirmiyah is treated as a special, borderline figure whose doubt is more dangerous than other people's doubt, even when his legal questions are no different from others'. ${ }^{37}$ R. Yirmiyah is no more of a scholastic than any other rabbi; the difference is that he is constructed as being one to an unacceptable degree.

Another R. Yirmiyah passage problematizes the relationship between unrealistic legal hypotheticals on the one hand and outright absurdity or parody on the other. In this passage, R. Yirmiyah's question is followed by the accusation that he was trying (unsuccessfully) to make R. Zeira laugh. I argue that this is another form of accusation about scholastic self-reflexivity, since the ability to joke about one's own intellectual endeavors presupposes a certain amount of detached self-analysis, which is the same attitude that makes possible the objectification and analysis of one's own practice in a serious register as well.

The passage appears in the course of a discussion about the first mishnah of the third chapter of tractate Niddah, which deals with strangely shaped miscarriages and their resultant impurity for the formerly pregnant woman. Once again, the passage that leads into R. Yirmiyah's question is itself quite logically

36. MS JTS Rab. 1608 (EMC 850) adds an extra line here: “And if you think that they didn't know."

37. R. Kahana's claim is then questioned in the continuation of this pericope, but in a completely serious manner. 


\section{Sarah Wolf}

fraught. Whereas previously we saw hermeneutic tension produced by a failed attempt at midrashic justification of a mishnaic law, the tension in this passage is produced by the Bavli's subtle conflation of a mishnaic legal fiction with a description of ontological reality.

After discussing miscarriages that are shaped like various objects, including fish, locusts, and reptiles, and determining that these result in blood impurity but not childbirth impurity, the Mishnah presents a disagreement between R. Meir and the sages about miscarriages shaped like birds and beasts:

[If a woman] miscarries something that looks like ${ }^{38}$ a domestic animal, wild animal, or bird, whether pure or impure, if it is male she sits [days of impurity] for a male and if it is female she sits for a female. If it is not known, she sits for a male and a female. These are the words of R. Meir. And the sages say: Whatever does not have in it [anything] of the shape of a man is not a [valid] offspring. ${ }^{39}$ (M. Niddah 3:2; MS Kaufmann)

The subsequent analysis of this mishnah attempts to determine what animals and birds have in common with humans such that R. Meir would rule that they result in normal childbirth impurity. The Talmud at first suggests a midrashic explanation for R. Meir (both humans and animals/birds are said to have been "created" in Genesis 1) and then an explanation based on physical resemblance (their eyes, or some feature of their eyes, are similar). Though this passage seems to be a straightforward search for an explanation of R. Meir's position, it also subtly elides the distinction between the shape of the miscarried objects and the very nature of those objects. In other words, the Talmud, without explicitly saying so, suggests the possibility that the mishnah refers not to a woman bearing a birdshaped fetus but to a woman giving birth to a real bird. ${ }^{40}$

38. Though some late textual witnesses of the Babylonian Talmud attest "a kind of domestic animal" (מין בהמה), the Kaufmann and Parma manuscripts of the Mishnah, the Leiden manuscript of the Yerusalmi, and Bavli manuscripts Vatican 127, Vatican 111, and Munich 95 all attest "something that is like a domestic animal" (כמין בהמה). This original version is not only more logical (a woman is much more likely to miscarry something that resembles a kind of animal than an actual animal) but is consistent with the language used in the first part of the Mishnah, attested in all witnesses as "Something that looks like [membranes, hair, dust, etc.]." It seems likely that the text was amended to "a kind of domestic animal" in later witnesses precisely because the discussion in the Talmud winds up imagining the fetus to be, in essence, a real animal.

39. In other words, the sages' position requires the presence of at least some - but not necessarily all-humanoid feature(s) in the miscarried substance in order to deem it a human fetus. This is how the sages here are understood in the Tosefta as well as the Palestinian and Babylonian Talmuds.

40. This is in fact how Rachel Rafael Neis reads the Mishnah here, arguing that "we must take the formula ' $k e-\min$ + creature' as far more than a rhetorical convenience, and instead as earnest formal criteria by which material is assessed." "The Reproduction of Species: Humans, Animals and Species Nonconformity in Early Rabbinic Science," Jewish Studies Quarterly 24, no. 4 (2017): 306. Though Neis makes a compelling point that "rabbinic reproductive biology implicates humans among and as animals" (293), and it is certainly the case that the borders between species are somewhat fuzzy here, Neis's claim works much better for the amoraic treatment of this material than it does for the tannaitic sources. 
The proffered explanations for R. Meir's position each hint at the possibility that these animal-shaped fetuses are real animals. The reference to the creation of animals and birds alongside humans suggests the presence of those beings themselves, not just their shapes. The second suggestion, which claims that animal/bird eyes resemble human eyes, seems less compatible with the notion that the fetuses are animal-like humans and more compatible with the idea that they are humanlike animals. If the key feature of animal-shaped human fetuses is their human eyes, why not refer to them as fetuses with humanoid eyes instead of calling them animal-shaped humans? This explanation for R. Meir's position makes much more sense if one considers the fetuses to be - at least at some levelactual animals, which R. Meir considers legally human because of their humanlike eyes.

Furthermore, the language of the discussion alternates between describing a woman miscarrying the "form of" some object and simply referring to a woman miscarrying the object itself. There seems to be an editorial shift at work here: in Hebrew statements by named Amoraim, the Talmud refers to "one who miscarries the form of a crocodile" and "one who miscarries the form of a mountain," whereas a presumably editorially constructed Aramaic reply refers to "one who miscarries a rock" and "one who miscarries wind." "Though the description of the object as its shape may be meant metaphorically and not as an ontological claim, the shift in language nonetheless paves the way for interpreting the mishnah as referring to a real animal as opposed to something that is merely animal shaped.

Whereas the initial discussion began to elide the distinction between animalshaped things and actual animals, the line between legal metaphor and reality is finally destroyed by R. Yirmiyah, who takes every part of R. Meir's position completely literally: "R. Yirmiyah asked R. Zeira: According to R. Meir, who said that an animal in a woman's womb is a valid [human] offspring, what if its father receives kiddushin on its behalf?"

R. Yirmiyah's question attempts to apply R. Meir's position to a case of presumably prenatal betrothal, asking about a hypothetical case in which the animal-fetus's father received a betrothal payment for it while it was still in the womb. ${ }^{42}$ R. Yirmiyah's question implies not only that the fetus is really an animal, as the previous discussion had subtly suggested, but that R. Meir's ruling that the formerly pregnant woman has childbirth impurity means that R. Meir considers the fetus completely normal for all other purposes as well.

R. Yirmiyah thus turns R. Meir's legal ruling, which creates a legal reality (the treatment of the miscarried matter as a normal human fetus for the purposes of impurity) that does not necessarily apply to other situations (e.g., betrothal), into a

41. The phrases "one who miscarries the form of a crocodile," "one who miscarries the form of a mountain," and "one who miscarries wind" each appear as part of the Hebrew statement: "But according to this logic, one who miscarries [the form of] X, its mother has / should have childbirth impurity!" The appearance of "one who miscarries wind" within this statement is likely a later editorial co-opting of amoraic formulaic phrasing.

42. See B. Kiddushin $62 \mathrm{~b}$. 


\section{Sarah Wolf}

necessarily contradictory description of ontological reality. Whereas R. Meir's legal position might be summarized as "something somewhat like an animal should be treated like a human in this one legal area," R. Yirmiyah's version of $\mathrm{R}$. Meir might sound something like: "R. Meir is saying an actual animal is a totally normal human baby!" As in the passages about sabbatical produce and ratios of water to bird-blood, R. Yirmiyah appears to be dissatisfied with legal fictions if they do not do a good job of accurately expressing physical realities.

At least part of the reasoning behind R. Yirmiyah's scenario - the conflation of animal-like fetuses with real animals - had already been subtly suggested by the previous discussion and in particular by the Talmud's anonymous voice, and the subsequent analysis of R. Yirmiyah's question rejects a different part of his premise as absurd.

What would be the legal significance [of this scenario]?

To prohibit [marriage to] its [presumably normal human] sister.

This implies that [the fetus] will live! [But] behold, R. Yehudah said in the name of Rav: R. Meir only said [it is valid] because it could live if born from its own kind.

R. Aha b. Yaakov ${ }^{43}$ said: up until then R. Yirmiyah was getting R. Zeira to laugh, but he did not laugh. (B. Niddah 23a)

In response to R. Yirmiyah's question, an anonymous voice asks what the legal implications of such a case would be, and responds that because it is forbidden to marry two sisters, then the fetus's sister would be prohibited to the prospective husband if the betrothal were valid and permitted if the betrothal turned out to be invalid. The anonymous voice then objects that this conversation is predicated on the assumption that the animal-fetus will live, since if one sister was betrothed and then died, it becomes permitted to marry the other sister. ${ }^{44}$

The opinion of Rav as quoted by R. Yehudah offers a rebuttal to the notion that the fetus will live, stating that R. Meir's reason for validating bird- and beastshaped fetuses is that they would survive if born to an animal of their own species. ${ }^{45}$ Rashi explains that the point here is that they would survive if born to their own species, but not otherwise; however, this is only the point when read within the context of the argument as constructed in this sugya. Taken by itself, Rav's opinion actually implies nothing about whether or not the fetus would survive if born to a human woman. ${ }^{46}$ The co-opting of this amoraic

43. Vatican 113, Munich 95, and Niddah G125 read "R. Aha b. Hanina."

44. See B. Yevamot $8 b$ for the specific derivation of this principle from the verse "You shall not take a woman to be a rival to her sister, to uncover her nakedness beside her, in her lifetime" (Lev 18:18).

45. As opposed to a miscarriage shaped like a membrane or some other object, which would never be a viable fetus of any species. See Tosafot ad loc.

46. And, in fact, the gufa discussing R. Yehudah's statement in the name of Rav ends with an attempt by Abbaye to disprove that the fetus will surely die, leaving the question of the fetus's viability ultimately unresolved. 


\section{"Haven't I Told You Not to Take Yourself outside of the Law?"}

statement shows that the redactor of this sugya wants to present a clear argument demonstrating that the fetus is not viable and hence that R. Yirmiyah's proposed (no pun intended) scenario is even more absurd than it might appear. Once again, R. Yirmiyah is set up by the Bavli's redactors to be harshly rejected and portrayed not just as wrong within the context of the debate, but as fundamentally engaging in a different sort of conversation from that which is considered to constitute acceptable legal discourse.

This anonymous discussion of R. Yirmiyah accepts that R. Meir's ruling implies both that a woman could be pregnant with an animal and that such an animal-fetus should be treated like a human in every respect. However, the anonymous voice disputes the premise that the animal-fetus might survive after being born, and for that reason deems R. Yirmiyah's scenario one that could never occur. In the final line of the analysis of R. Yirmiyah's question, another rabbi deems the entire question not just an impossible scenario but an intentional joke. By shifting the focus of improbability to the survival of the fetus as opposed to the possibility that a woman might give birth to an actual animal, the passage implicitly accepts R. Yirmiyah's broad and literal reading of R. Meir's statement. ${ }^{47}$ Instead, R. Yirmiyah is accused of making a joke - perhaps an accusation of displaying levity in a manner inappropriate for the seriousness of the study house, but perhaps yet another depiction of R. Yirmiyah as overly detached from the subject matter at hand. ${ }^{48}$ Whereas according to his portrayal in other passages, his metaanalysis of standard rabbinic thought processes causes R. Yirmiyah to express skepticism, in this case-as often happens when one stops what one is doing and thinks about it critically_it causes him to laugh. This can be seen, then, as another form of unacceptably scholastic self-reflexivity, taken here to a different extreme: humor instead of doubt.

The special rebuke that $\mathrm{R}$. Yirmiyah is subjected to here is made even more apparent by comparing his question with both the Palestinian Talmud's treatment of R. Meir's position and a question by a different rabbi that appears later in the Bavli sugya. The Palestinian Talmud's analysis of R. Meir's ruling is quite similar to R. Yirmiyah's:

R. Haggai said in the name of R. Hanina: The rabbinic fellows made the following challenge to [the statement] of R. Meir. [If a woman] miscarried the shape of a raven, [someone] stands at the top of the palm tree and says to it: "Come and perform halizah or yibum"?! (Y. Niddah 3:2 [50c], p. 1443)

47. A thematically similar passage that contains a surprisingly unacceptable question, very difficult structural logic, and potentially nonviable fetuses appears at B. Menahot $37 \mathrm{a}$. That passage and the one at hand both seem to reveal some unresolved internal ambivalence about whether or not one can always assume that monstrous births will not survive.

48. Like others who have attempted to explain these passages, R. Aha b. Yaakov seems to be reading across or at least picking up on themes in other stories: despite the fact that $\mathrm{R}$. Yirmiyah is never explicitly rebuked in the Niddah sugya, R. Aha b. Yaakov nonetheless claims that R. Zeira did not laugh, echoing R. Zeira's disapproval of his colleague elsewhere. 


\section{Sarah Wolf}

This challenge is similar in both tone and import to R. Yirmiyah's question in B. Niddah. Both R. Yirmiyah and R. Haggai dispute R. Meir's position by treating its legal logic as a kind of descriptive ontological statement. They read R. Meir's legal metaphors - a fetus that looks like a bird; a miscarried fetus that is considered human - as though they were statements about reality: a bird that doesn't just look like but acts like a bird, and a human that is not just legally a fetus but a normal human for all intents and purposes.

In the context of the mishnah, however, R. Meir's ruling that "it is a human offspring" seems intended only to affect the length of time that the formerly pregnant woman will be impure, but not to make any claims about the fetus's role in other legal contexts. The mishnah is explicitly discussing a miscarriage, not a fullterm, viable pregnancy, so presumably the question of whether the miscarried fetus would have grown up to be a normal human was not even a consideration. Yet both R. Yirmiyah and the rabbis in the Yerushalmi imagine R. Meir's designation of "valid human offspring" to mean not only that its mother must determine its gender and count her days of impurity accordingly, but that the fetus could and even should be expected to have normal human relationships with spouses and siblings. R. Yirmiyah's question uses the example of prenatal betrothal for a female animal-shaped fetus, while the rabbis' challenge in the Yerushalmi imagines a case in which a male raven-shaped fetus had a married brother who died, leaving the raven-fetus to either perform levirate marriage for the brother's widow or officially release her. Furthermore, just as R. Yirmiyah (in accordance with the rest of the discussion in the Bavli) implies that the object in the woman's womb is a true animal, R. Meir's detractors in the Yerushalmi imagine the miscarried raven-shape to be a true bird - hence the need to address it from the top of a tree.

Whereas the Yerushalmi parallels R. Yirmiyah's rather flat-footed reading of R. Meir in content if not form, the discussion of R. Meir in the Bavli offers a structural parallel to R. Yirmiyah's question and its attendant discussion, showing once again that R. Yirmiyah is unique not because of the content of his questions but because of the way his questions are responded to. Shortly following R. Yirimyah's question, the Bavli continues to probe R. Meir's position with a question and subsequent analysis that is nearly identical in structure to R. Yirmiyah's:

R. Ada b. Matna ${ }^{49}$ asked Abbaye: According to R. Meir, who said that an animal born from a woman's womb is a valid offspring, what about a human in an animal's womb?

What would be the legal significance?

To permit it for eating.

But [one may] answer from that which R. Yohanan [said], for R. Yohanan said: One who slaughters an animal and found in it the shape of a dove, it is forbidden for eating.

49. Vatican 113 and Niddah G125; Vatican 111 and Munich 95 read "R. Matna"; and the Soncino and Vilna prints read "R. Ada b. Ahava." 
Once again, the Bavli offers a (quoted) summary of R. Meir's position in which its legal metaphors are turned into ontological statements; a question as to what R. Meir would say about a particular reductio ad absurdum situation; a counterquestion and response regarding the legal significance of the given situation; and finally a statement by an earlier Amora that is apparently intended to reject the entire premise of the question. Yet here there is no suggestion that the scenario was offered as a joke. In fact, the legal question is affirmed to be a valid one, so much so that just like in the previous example, it has already been asked in another context and answered by another rabbi. ${ }^{50}$

Both the challenge about the raven in the Yerushalmi and the parallel to R. Yirmiyah's question in the Bavli take a position on the mishnah that is, each in its own way, taken seriously: the response to R. Meir in the Yerushalmi is presented as a valid challenge to $\mathrm{R}$. Meir in the form of a reductio ad absurdum, and R. Ada b. Matna's parallel question is presented as a legitimate (if unnecessary) legal question, a version of which has already been discussed and answered elsewhere. In the case of R. Yirimyah's question, however, the anonymous voice then attempts to reject the entire premise of the question: R. Yirmiyah could never have seriously thought that the animal-fetus would live; rather, he was asking the question as a joke, perhaps even a sort of parody of a talmudic hypothetical.

R. Aha b. Yaakov's claim that R. Yirmiyah's question is a joke can be read as a comment not only on this passage but on the portrayal of R. Yirmiyah throughout the Bavli. ${ }^{51}$ The phrase meaning "up until then" (עד כאן) suggests that R. Yirmiyah's attempt to make R. Zeira laugh has been ongoing, and since this is the only such statement by R. Yirmiyah in the chapter, it is hard to understand it other than as a late comment on R. Yirimyah's character in the Bavli as a whole. ${ }^{52}$ We thus see further evidence of the construction of R. Yirmiyah's character as consistently predisposed to problematically scholastic reactions to rabbinic modes of thought.

In yet another passage, R. Yirmiyah's question is not merely verbally rebuked or described disparagingly, but actually results in his expulsion from the house of study. This legal narrative appears during the discussion of the mishnah's rules about how to determine ownership of a bird that has fallen out of its nest or coop. The mishnah states that if the bird was found within fifty cubits of a coop, it is considered to belong to the coop's owner. If it is more than fifty cubits away from a coop, its finder may keep it. If it is found between two adjacent coops, it belongs to the owner of the closer coop. Finally, the mishnah states, "Half and half, the two split it."

As in the previous two passages, R. Yirmiyah's question appears in the middle of a sugya that has gotten off to a logically strained start. The discussion

50. And, indeed, the opinion of R. Yehudah here also appears at B. Hullin 69a.

51. This is also how Rashi reads it, ad loc.

52. R. Yirmiyah does ask R. Zeira a question earlier in the chapter, at B. Niddah $21 \mathrm{~b}$, but like most of R. Yirmiyah's questions in the Bavli, it is treated as a normal and serious one. 


\section{Sarah Wolf}

of this mishnah begins with a series of exchanges between R. Zeira and R. Hanina about whether or not there is a general conceptual rule that determines law in the case of doubt. The topic of the discussion is R. Hanina's statement that in legal cases of doubt, one must always rule according to probability based on majority rather than probability based on proximity. ${ }^{53} \mathrm{R}$. Zeira's initial response seems to be a decisive refutation of R. Hanina's claim: in the biblical case of the brokennecked calf, Deuteronomy explicitly states that the job of providing the ritual animal falls to the elders of whichever city is closest to the corpse. R. Zeira rightly points out that this seems to be the law regardless of whether one city is more populous than another. R. Hanina's position is defended by the Talmud's anonymous voice, sparring with an anonymous representative of $\mathrm{R}$. Zeira. However, its claims are rather weak.

First, the anonymous voice argues that when the Torah says "whichever city is closest," it is referring to a case where there is no city that is both larger and farther away. This reading is somewhat difficult, since it ultimately claims that "closest" actually just means "largest." 54 Next, R. Zeira or his anonymous defender suggests that if majority really took precedence, the Torah would point to the largest city anywhere. The anonymous voice responds that the Torah is referring to a case where the corpse was found in the mountains, and was thus presumably hard to reach from far away. This again seems like an unlikely interpretation - not only does the Torah not say such thing, but it in fact explicitly says that the corpse was found in a field. Up to this point, R. Hanina's position seems rather unconvincing. ${ }^{55}$

The connection between this argument and the mishnah becomes apparent when R. Zeira's side then counters by pointing out that the law of the fallen bird also privileges proximity over majority, since the mishnah does not ask which coop contained more birds, but attributes ownership based on which coop is closer.

It is taught in a mishnah: "A fallen [bird] that was found within fifty cubits, behold, it belongs to the owner of the coop"-even if there is another [coop] that is more populous.

53. This phrase also appears at B. Bezah $10 \mathrm{~b}$ and $11 \mathrm{a}$, though without the rest of the statement about competing principles from the Torah. "Between majority and proximity we follow the majority" is in Hebrew; the rest of R. Hanina's statement is in Aramaic and thus possibly a later addition.

54. Rashi understands the case where there is no city both larger and farther away to mean that all of the nearby cities are of equal size. This is a somewhat better reading, since it is possible to imagine that the Torah speaks of an ideal legal situation in which all other factors such as population size are controlled for. However, the truly weak suggestion that follows this one makes me inclined to read the pro-R. Hanina anonymous voice less charitably, since it does not seem designed to be truly compelling.

55. R. Hanina’s position is also dismissed when it appears at B. Bezah 10b and 11a. 


\section{"Haven't I Told You Not to Take Yourself outside of the Law?"}

[No,] if there isn't one.

[But] note that the last clause says: "Outside of fifty 'amot, it belongs to its finder." If there isn't [another] one [that is more populous, ${ }^{56} \operatorname{then}^{57}$ of course it fell from this one! $!^{58}$

Here what are we dealing with? With a [bird] that [only] hops, as R. Ukva b. Hama said: Any [bird] that hops cannot hop more than fifty ['amot]. (B. Bava Batra 23b)

The anonymous defender of R. Zeira points out that the mishnah does not ask which coop contained more birds, but attributes ownership based on which coop is closer. Just as it did in the discussion of the unknown corpse, the anonymous R. Hanina voice again suggests that this rule is referring to a case in which there is no coop that is both larger and closer. R. Zeira's side disputes this reading on the basis that if so, the claim that "outside of fifty 'amot it belongs to its finder" is problematic, since in that case the bird clearly belongs to the coop under consideration.

Finally, R. Hanina's anonymous defender answers by quoting another Amora, R. Ukva b. Hama, who claims that the mishnah refers to a bird that cannot fly but can only hop - that is, a baby bird. ${ }^{59}$ Since according to this Amora, baby birds cannot hop more than fifty 'amot, it is not a legal ruling but a fact of nature that if a chick was found more than that distance from the coop, it could not have originated in the coop. Upon closer consideration, however, this position is quite logically difficult. If it did not originate in the coop and there is no other coop around, how did it get there? ${ }^{60}$

Only after R. Hanina's claim has been not especially convincingly defended does R. Yirmiyah enter with his exile-worthy question. Following this back-and-forth, R. Yirmiyah asks: "If one of its feet was within fifty 'amot and one was outside fifty 'amot, what is the ruling?" No response is given, but an anonymous voice then relates, "It was because of this that they threw R. Yirmiyah out of the house of study." ${ }^{\text {. }}$

56. Bracketed phrase attested in MS Hamburg Cod. 19.

57. Cremona - Archivio di Stato Fragm. 71, Florence II-I-9, and Paris 1337 attest: "Then why does it belong to the finder? Of course it fell from this one!"

58. MS Hamburg Cod. 19 attests at this point: "And furthermore, according to R. Zeira, who said that 'Between majority and proximity we follow the majority,' if there is not another one closer than this one, then of course it is from this one."

59. The statement of R. Ukva b. Hama also appears at B. Beẓah 11a.

60. One possible answer would be "from a tree," but the entire passage here does not seem to consider the possibility of birds' existences outside of their ownership by humans, so this solution would likely not be considered within the passage's internal logic.

61. Other stories in the Bavli about sages who are expelled from the house of study include Rabban Gamaliel's removal of R. Meir and R. Natan from the academy for attempting to depose him at B. Horayot 13b-14a, and R. Ami's expulsion of a disciple as a consequence for revealing a secret at B. Sanhedrin 31a. The passage at B. Menahot 37a mentioned above is the closest parallel to this anecdote about R. Yirmiyah: An interlocutor of R. Judah the Prince who asks a hypothetical question ("If one has two heads, on which one should he place his tefillin") is told to leave the 


\section{Sarah Wolf}

At first glance, R. Yirmiyah's question appears problematic because it seems to have just been answered by the mishnah itself: "Half and half, the two split it!" If this is the case, then R. Yirmiyah's question has no actual content, and can be read as merely a parody of a rabbinic question. Eliezer Diamond takes this position, arguing that R. Yirmiyah's question should be understood as mocking a question asked by R. Hanina elsewhere about a person with one foot inside the Shabbat boundary and one foot outside of it. ${ }^{62}$

However, it is also possible to understand R. Yirmiyah's question as a real one - not a parody of R. Hanina's question but rather, as we have seen in the other $\mathrm{R}$. Yirmiyah anecdotes, a question just like other rabbinic questions that is nonetheless uniquely subjected to collegial rebuke. R. Yirmiyah may see the two halves of the mishnah as relatively self-contained: the second half, which contains the provision about splitting the value of the bird, deals with the rights of two professional bird owners who could reasonably be owners of this particular bird. The first half, on the other hand, deals with the right of one professional bird owner and one finder who all agree never owned the bird initially, and whose right to the bird is only triggered by the departure of the bird from its owner's domain; thus, the provision about splitting its value may not apply, since the competing possible claims to ownership do not start off on equal footing, so to speak. R. Yirmiyah could thus be asking his question about the first half of the mishnah only, and thus, as in previous passages, asking a question that echoes other serious rabbinic questions yet is treated as distinctively problematic. ${ }^{63}$

This passage also echoes other elements of the other R. Yirmiyah anecdotes we have already seen. Like his question about the betrothal of an animal-fetus, R. Yirmiyah's question here presents an improbable hypothetical scenario. And much like R. Yirmiyah's doubts about the establishment of measurements through the use of legal presumptions, his question about the liminal bird again casts doubt on the utility of legal presumptions - in this case as a method of determining ownership - and in so doing casts doubt on, or at least ignores the importance of, the functional authority of rabbinic ownership law. The phrasing of the narrative itself suggests that R. Yirmiyah's expulsion was either already known to the reader or a narrative inevitability: rather than stating simply "they expelled him from the house of study," they expelled R. Yirmiyah from the house of study"-as though either the reader already knows that R. Yirmiyah was expelled at one point, and this story clarifies why; or else the reader is already familiar with the other R. Yirmiyah anecdotes and knows that nothing happened as a result of all the other instances, and

house of study or else accept a ban upon himself. However, like R. Yirmiyah, the questioner in Menahot 37 a does not wind up permanently banished. For a general discussion of rabbinic expulsion from the academy, see Rubenstein, Culture of the Babylonian Talmud, 141.

62. Diamond, "But Is It Funny?," 42.

63. An anonymous reviewer of this article also suggested that R. Yirmiyah could be responding to R. Ukva b. Hama's claim that baby birds can only hop fifty 'amot with a genuine question about whether they can hop fifty and one-half 'amot or not.

64. Cf. B. Sanhedrin 31a, אפקיה רבי אמי מבי מדרשא, and B. Horayot 13b, פקיד ואפקינהו מבי מדרשא. 
therefore the narrative states that, in contrast, because of this there were consequences. If read through this second lens of literary inevitability, then, the trouble with R. Yirmiyah's question here is not just its content but its repetition. R. Yirmiyah just won't quit, and it is because of this - not necessarily the worst offense, but the last straw - that the rabbis finally throw him out.

Both the narrative continuity and the metaphorical resonance of R. Yirmiyah's expulsion are further emphasized by the "conclusion" of this narrative much later on in the same tractate. ${ }^{65}$ In the context of an entirely different legal discussion, several different narratives are presented about how R. Yirmiyah came to be reinstated. In each version of the story, the rabbis collectively send R. Yirmiyah a legal question, and each of his responses is phrased in such a way that it could also be interpreted as an expression of R. Yirmiyah's desire to reenter the academy. The first question, "One who bore witness in writing and one who witnessed orally - can they be joined?" provokes the response, "Thus the opinion of your student inclines: that they can/should be joined [שיצטרפו]." The second version of the question, "Two who witnessed, one in this courthouse and the other in that courthouse - can one courthouse come to another so they can be joined?" again generates the response, "They can/should be joined." The third version, too, asks about witnesses, and again R. Yirmiyah responds, "They can/ should be joined." In each case, R. Yirmiyah's response does not specify "witnesses," but merely affirms the permissibility or desirability of joining, evoking the act of his own subsequent reinstatement. Just in case the literary resonance of "joining" were not enough, the final version of the sages' question for R. Yirmiyah is explicitly about acknowledging the loss of a colleague: "Three who sat to uphold a document and one of them died, is it necessary to write during the session 'We were three, and one is absent?" R. Yirmiyah answers, "It is necessary to write during the session 'We were three, and one is absent." This response also evokes R. Yirmiyah's absence from his colleagues and perhaps even hints that they ought to be more cognizant of his loss from the house of study.

In this legal narrative, R. Yirmiyah and the rabbis use the language of law to communicate about their own relationship as colleagues. Behind what seems to be a standard exchange of legal questions and answers, the legists are expressing powerful emotions of longing for fellowship, the experience of a colleague's absence, and the desire to connect. This story's literary features are thus not limited to the creation of a kind of "plot," albeit a nonlinear one, in conjunction with the other R. Yirmiyah anecdotes, but exist on the level of evocative imagery as well. This is also true of the story of R. Yirmiyah's initial expulsion: if R. Yirmiyah is portrayed as already having set himself up for trouble with his previous problematic questions, then the image of the bird with one foot inside a boundary and one foot outside is a striking metaphor for the status of R. Yirmiyah himself as he asks the question. R. Yirmiyah is thus established as a liminal scholastic character through several elements of these passages' literary 


\section{Sarah Wolf}

construction, both in the imagery of his initial question and in the description of his reinstatement.

R. Aha b. Yaakov's characterization of R. Yirmiyah as a jokester at Niddah $23 \mathrm{a}$ is in a way representative of the voice of the later interpreter, whether ancient or modern, whom the text pushes into finding some way to explain the consistently critical treatment of R. Yirmiyah. R. Aha b. Yaakov reads R. Yirmiyah as doing the work of halakhic reasoning in an intentionally (and inappropriately) silly wayeven though R. Yirmiyah's questions in that passage seem no more or less silly than many other discussions of law throughout the Bavli.

One could argue that a great deal of the Talmud is at some level meant to be silly, and that it is through the character of R. Yirmiyah that this tendency is remarked upon. However, there are good reasons to remain agnostic as to whether scenarios like these, along with many other scenarios throughout the Bavli involving events such as elephants defecating baskets, weasels swallowing fetuses and vomiting them back up, or men penetrating themselves are intended to be humorous. ${ }^{66}$ Just because the modern reader finds them to be so does not mean this was the point of generating such scenarios - the more legally liminal a scenario is, the funnier the reader is likely to find it, and it is difficult, if not impossible, to determine which came first for the Bavli. ${ }^{67}$

Without having to pass judgment on the comedic intent of the Bavli's case law, one can read the R. Yirmiyah stories as moments of "calling out" some aspects of the Bavli's legal discourse that are actually fairly ubiquitous - and, it seems, that the Bavli's creators feel ambivalent enough about to perform seriously everywhere else. R. Aha b. Yaakov's characterization does not necessarily provide information about whether R. Yirmiyah's question about fetuses or any of his other questions were meant to be funny, but it does tell us that a question that is very similar to other rabbinic questions can be understood by another rabbi as humorously absurd. These passages, then, may betray the rabbis' awareness that the sorts of questions they ask, if viewed through the right lens, could be understood as something like parodies of legal scholasticism-as performances of caricatures of themselves.

We can perhaps consider R. Yirmiyah's questions to be the talmudic equivalent of "how many angels can dance on the head of a pin," a question that no medieval scholastic ever asked, but which was made up in order to caricature the nature of scholastic questions. (In fact, one historian has suggested that the original form

66. B. Menahot 69a, B. Hullin 70a, B. Sanhedrin 75a.

67. A famous case that is often taught to first-year law students, Riggs v. Palmer, deals with the validity of a will bequeathing a grandfather's estate to his grandson when said grandson, fearing a change to the will, had poisoned the grandfather. The absurdity of this case, indeed the humor, if one ignores the fact that this befell real people, is inseparable from the aspects that make it a useful tool for thinking through a tricky legal question. Simple cases are neither useful nor funny. For a description of various approaches to this case by legal writers from Cardozo to Dworkin, see Kenneth S. Abraham, "Statutory Interpretation and Literary Theory: Some Common Concerns of an Unlikely Pair," in Interpreting Law and Literature: A Hermeneutic Reader, ed. Sanford Levinson and Steven Mailloux (Evanston, IL: Northwestern University Press, 1988), 115-29. 


\section{"Haven't I Told You Not to Take Yourself outside of the Law?"}

of the question involved a pun on "needle's point" and "needless point.") ${ }^{68}$ Like R. Yirmiyah's questions, this question is effective as a caricature because it does touch on real elements of the culture it seeks to satirize - medieval Christian scholastics were genuinely interested in angelology, and Thomas Aquinas's Summa theologica in fact contains a section addressing the question of whether several angels can be in one place at the same time.

Christine Hayes has also written about the rabbis' use of mockery to engage in self-critique about aspects of their legal discourse. Hayes analyzes several passages in which Palestinian rabbis are described as mocking Babylonian rabbis when the latter propose legal interpretations that privilege legal facts over observable reality in the determination of the rabbinic legal world. ${ }^{69}$ Hayes claims that this description of mockery serves as a trope through which the Babylonian rabbis can express some of their own discomfort with their legal methodology. In particular, Hayes sees these passages as manifesting the Babylonian rabbis' awareness of their own tendencies towards nominalist, or what Hayes calls "minddependent," law - that is, treating legal facts as real regardless of their correspondence with external realities. ${ }^{70}$ According to Hayes, the rabbis were aware that this approach towards law was not necessarily shared by other contemporaneous legal cultures, and they express self-consciousness about this through the mouths of outsiders (here, Palestinians). ${ }^{71}$

Like the passages about the mocking Palestinians, the R. Yirmiyah sugyot also express ambivalence about the rabbis' legal discourse. R. Yirmiyah himself serves as a liminal figure as a rabbinic insider but a geographic outsider. ${ }^{72}$ Not only is he a Palestinian, but he is at one point in the Bavli deemed the author of every statement attributed to the rabbis "in the west"- so he may even be considered a kind of Palestinian archetype. ${ }^{73}$

68. Peter Harrison, “Angels on Pinheads and Needles' Points,” Notes and Queries 63 (January 2016): $45-47$.

69. Hayes, "In the West."

70. The terms "mind-independent" and "mind-dependent," preferred by Hayes, have been more commonly referred to in Jewish studies as "realism" and "nominalism," respectively. Within the context of discussions about late ancient Jewish law, realism is defined as the notion that concepts exist independently of the legislator and that law does not have the power to create new (often abstract) entities in the world. Nominalism, on the other hand, is the belief that concepts can be brought into existence and become truly "real" by means of legislation, regardless of whether or not they have any sort of externally verifiable truth. Hayes has repeatedly argued that although Jewish law is mainly realist, it possesses more of a tendency towards nominalism than other ancient conceptions of divine law.

71. Both Hayes and Richard Kalmin have also written about the literary displacement of rabbinic self-criticism onto non-Jewish characters in rabbinic literature: Hayes, "Displaced SelfPerceptions: The Deployment of Minim and Romans in Bavli Sanhedrin 90b-91a," in Religious and Ethnic Communities in Later Roman Palestine, ed. Hayim Lapin (Potomac: University Press of Maryland, 1998), 249-89; and Kalmin, Jewish Babylonia between Persia and Roman Palestine (Oxford: Oxford University Press, 2006), 87-102.

72. Hayes refers to such figures as "internal others." "In the West," 142.

73. B. Sanhedrin 17b. R. Yirmiyah is also often quoted as explicitly denigrating Babylonian thought; see, for example, B. Yoma 57a and B. Sanhedrin 24a. 


\section{Sarah Wolf}

The R. Yirmiyah passages, however, do not fit so neatly into a nominalism/ antinominalism framework. It is true that in their engagement with the relationship between law and reality, R. Yirmiyah's questions do contain elements that suggest a critique of nominalism along the lines of the "in the west" passages. In particular, R. Yirmiyah seems to be calling into question the use of legal presumptions in several of the above passages, such as the use of the one-third standard for grain growth. This is, at least, certainly how he is portrayed by R. Zeira's response not to "take [him]self outside hilkheta."

On the other hand, the questions themselves are hypotheticals that continue along the already-established premises: they don't mock the nominalist nature of the rabbinic arguments so much as take it to an extreme. Furthermore, the stories about the mocking Palestinians - especially as analyzed through the lens of whether, and to what extent, the rabbis were nominalists - generally reflect discomfort about the employment of specific legal means towards a practical end. In other words, the question at hand for the mocked Babylonian rabbis, at least according to Hayes, is whether a given case ought to be dealt with from a nominalist perspective, that is, by creating some kind of legal fiction or otherwise privileging legal facts over empirical acts. This ambivalence about nominalism likewise seems to be at play in R. Yirmiyah's expression of doubt regarding the rabbis' ability to determine one-third growth of wheat. In other R. Yirmiyah stories, however, such as the passage about the animal-like fetus, the ambivalence seems less about different sorts of mechanisms for determining legal outcomes and more about a generalized self-consciousness about the increased abstraction, sometimes even to the point of absurdity, of rabbinic legal discourse. The selfconsciousness expressed through the portrayal of R. Yirmiyah may therefore be not so much about legal means as about legal ends (or lack thereof): Should legal discourse entail discussion of scenarios that are useful only for their theoretical implications? In other words: How scholastic should the rabbinic textual community be?

The tension expressed through the character of R. Yirmiyah in these passages, then, is not so much about the rabbis' specific philosophy of law as it is a question of the purpose of thinking about law altogether. The legal self-critique here, then, is not necessarily about specific legal strategies, but rather a larger issue of more literary, playful, conceptual, and nonstatutory legal impulse. The depictions of R. Yirmiyah's questions and their consequences represent moments of concern about whether they have taken this impulse too far-that rabbinic legal discourse may become so internally focused that it becomes primarily an intellectual exercise, and perhaps not even really "law" at all. These moments of raising this doubt and then quelling it are ultimately what allows the Talmud to continue taking seriously its work of legal debate and analysis, creating a legal scholastic culture that affirms even the most apparently ridiculous business. 